\title{
Identifikasi dan pemetaan tingkat lahan kritis wilayah dataran menengah Kabupaten Probolinggo menggunakan teknik sistem informasi geografi (SIG)
}

\section{Identification and mapping of critical land levels in the middle plains of Probolinggo Regency using geographic information system (GIS) techniques}

Purwadi $^{1 *}$ dan Siswanto ${ }^{2}$

${ }^{1}$ Program Studi Agroteknologi. Fakultas Pertanian. UPN "Veteran” Jawa Timur. Indonesia

*Email korespondensi: purwadi@upnjatim.ac.id

Diterima: 01 Oktober 2020 / Disetujui: 02 Februari 2021

\begin{abstract}
ABSTARCT
The middle plains area of Probolinggo district has the potential to experience land degradation due to intensive agricultural land use without paying attention to the principles of soil and water conservation. This condition is corroborated by information from the Probolinggo Regency Environmental Agency (BLH), that the mid-plain area has experienced a continuous decline in production. This study aims to identify the status of damage and criticality of land by compiling a spatial database system for allocating critical land data. The research locations included Sumber Asih, Wonomerto, Bantaran, Maron, Krejengan, Tegal Siwalan and Pakuniran subdistricts.The research was conducted using the Geographic Information System which is divided into main activities, namely: Identification of damage and spatial analysis by overlapping maps for making studies of spatial administration, land cover, land use, and erosion maps by calculating the amount of soil erosion. Brightness factor, land cover is used to analyze the distribution of land criticality. Broadly speaking, the analysis stages of the spatial data preparation of critical land consist of 3 stages, namely: Overlapping spatial data, editing attribute data and tabular analysis. The conclusion is the status of soil damage including mild to moderate damage, and critical status classified as non-critical status covering an area of 15,613.22 ha (43.35\%), critical potential 10,942.66 ha (30.38\%), rather critical area of 8,134.56 ha. $(22.58 \%)$, critical area of $196.23 \mathrm{ha}(0.54 \%)$ and very critical area of 1.131 .01 ha (3.14\%).
\end{abstract}

Keywords: critical land, GIS, land degradation

\section{ABSTRAK}

Wilayah dataran menengah kabupaten Probolinggo berpotensi mengalami degradasi lahan diakibatkan pemanfaatan lahan pertanian yang intensif tanpa memperhatikan kaidah konservasi tanah dan air. Kondisi tersebut dikuatkan oleh informasi Balai Lingkungan Hidup (BLH) kabupaten Probolinggo, bahwa wilayah dataran menengah telah mengalami penurunan produksi secara kontinu. Penelitian ini bertujuan mengidentifikasi status kerusakan dan kekritisan lahan dengan menyusun sistem database keruangan untuk pengalokasian data lahan kritis. Lokasi penelitian meliputi kecamatan Sumber Asih, Wonomerto, Bantaran, Maron, Krejengan, Tegal Siwalan dan Pakuniran. Penelitian dilakukan dengan menggunakan Sistem Informasi Geografi yang dibagi dalam kegiatan utama yaitu: Identifikasi kerusakan dan analisis spasial dengan tumpang susun peta untuk pembuatan kajian spasial administrasi, tutupan lahan, penggunaan lahan, dan Peta erosi dengan menghitung besarnya erosi tanah. Faktor kelerangan, tutupan lahan digunakan untuk analisis sebaran kekritisan lahan. Secara garis besar tahapan analisis penyusunan data spasial lahan kritis terdiri dari 3 tahap yaitu: Tumpang susun data spasial, Editing data atribut dan Analisis tabular. Kesimpulannya adalah status kerusakan tanah termasuk rusak ringan sampai sedang, dan status kekritisan tergolong status tidak kritis seluas 15.613,22 ha (43,35\%), potensial kritis 10.942,66 ha (30,38\%), agak kritis seluas 8.134,56 ha (22.58\%), kritis seluas 196,23 ha (0,54\%) dan sangat kritis seluas 1.131,01 ha (3,14\%).

Kata kunci: Lahan kritis, GIS, degradasi lahan

\section{PENDAHULUAN}

Kabupaten Probolinggo terletak di lereng pegunungan yang membujur dari Barat ke Timur, yaitu Gunung Semeru, Argopuro, Lamongan dan Tengger, Berdasarkan pengamatan dilapangan penggunaan lahan terdiri dari sawah, tegal, Tambak, pemukiman dan hutan. Penggunaan untuk lahan pertanian cukup intensif, sehingga potensi terjadinya degradasi lahan sangat besar, Awal terjadinya lahan krtitis disebabkan pengelolaan lahan yang intensif tanpa memperhatikan kaidah-kaidah konservasi tanah dan air. Berdasarkan Peraturan Pemerintah (PP) Nomor 150 tahun 2000 tentang Pengendalian Kerusakan Tanah untuk Biomassa. Peraturan Pemerintah bertujuan agar pemanfaatan 
tanah dilakukan dengan mempertimbangkan kemampuan tanah, sehingga tanah bermanfaat secara berkelanjutan dengan tetap berproduksi dengan yang baik dan optimal.

Hasil penelitian yang telah dilakukan oleh Purwadi dan Siswanto, (2019) di wilayah dataran tinggi menunjukkan lahan dikategorikan rusak ringan dan rusak sedang. Sedangkan berdasarkan hasil survei awal di wilayah dataran menengah berpotensi mengalami kerusakan lahan diakibatkan pemanfaatan lahan pertanian yang intensif tanpa memperhatikan kaidah konservasi tanah dan air.

Salah satu cara untuk mengindentifikasi keberadaan dan sebaran lahan kritis di kabupaten Probolinggo, yaitu dengan memanfaatkan teknologi Sistem Informasi Geografi (SIG) Nugrogo dan Prayogo (2008). Dengan teknologi ini akan memudahkan dalam menganalisis serta menentukan sebaran lahan kritis. Kelebihan lain dari data digital adalah proses analisis peta lebih lanjut dapat dilakukan dengan cepat dan tepat. Kondisi tersebut sangat bermanfaat untuk meningkatkan kinerja dari para pengambil kebijakan dalam mengambil kebijakan yang berkaitan dengan lahan kritis.

Penelitian ini bertujuan untuk mengidentifikasi status kekritisan lahan dan menyusun sistem database keruangan untuk pengalokasian data-data tentang lahan kritis di wilayah dataran menengah kabupaten Probolinggo. Lokasi penelitian meliputi kecamatan Sumber Asih, Wonomerto, Bantaran, Maron, Krejengan, Tegal Siwalan dan Pakuniran.

\section{Pengertian Lahan Kritis}

Pengertian lahan kritis antara suatu lembaga dengan lembaga lainya berbeda-beda, hal ini disebabkan karena perbedaan sudut pandang dari pengguna. Lahan kritis dibidang pertanian berkaitan dengan produktivitas lahan (kemampuan berproduksi dari suatu lahan), sedangkan dari sudut pandang kehutanan dan pelestarian lingkungan melihat lahan kritis berhubungan dengan fungsi lahan sebagai media pengatur tata air, media produksi hasil hutan dan sebagai media proteksi banjir dan/atau sedimentasi bagian hilir Didu (2001) dalam Indrihastuti, Murtilaksono, Tjahjono (2016).

Lahan kritis menurut Peraturan Pemerintah Nomor 26 Tahun 2020 dalam Rehabilitasi dan Reklamasi Hutan adalah lahan yang berada di dalam dan di luar kawasan hutan yang menurut fungsinya sebagai unsur produksi dan media pengatur tata air DAS.

\section{Parameter Lahan Kritis}

Hasil analisis beberapa parameter penentu kekritisan lahan menghasilkan data spasial kekritisan lahan (Wahyuningrum, dan Basuk, 2019). Parameter penentu lahan kritis berdasarkan Permenhut Nomor P.32/Menhut-II/2009, meliputi : Penutupan lahan, Kemiringan lereng, Tingkat bahaya erosi, dan Manajemen Lahan. Sedangkan menurut Peraturan Dirjen Pengendalian DAS dan Hutan Lindung Nomor P.3/PDASHL/SET/KUM.1/7/2018. Tentang Petunjuk Teknis Penyusunan Data Spasial Lahan Kritis meliputi variabel : tutupan lahan, kemiringan, tingat bahaya erosi, dan wilayah/kawasan. Dalam peraturan tersebut mengatur besarnya kehilangan tanah (erosi) dinyatakan dalam ton/ha/tahun.

\section{BAHAN DAN METODE}

\section{Lokasi dan Waktu Penelitian}

Lokasi Penelitian berada di lahan dataran menengah meliputi 7 (tujuh) Kecamatan dengan titik pengamatan di setiap kecamatan yang tertera pada tabel 1 . Penelitian ini dilakukan mulai Mei - Juli 2020. Wilayah administrasi daerah penelitian disajikan dalam Gambar 1.

Tabel 1. Lokasi dan Titik Pengamatan

\begin{tabular}{ccc}
\hline No & Kecamatan & Ketinggian $(\mathrm{dpl})$ \\
\hline 1 & Pakuniran & 610 \\
2 & Bantaran & 425 \\
3 & Wonomerto & 410 \\
4 & Sumberasih & 406 \\
5 & Tegalsiwalan & 630 \\
6 & Maron & 410 \\
7 & Krejengan & 540 \\
\hline
\end{tabular}




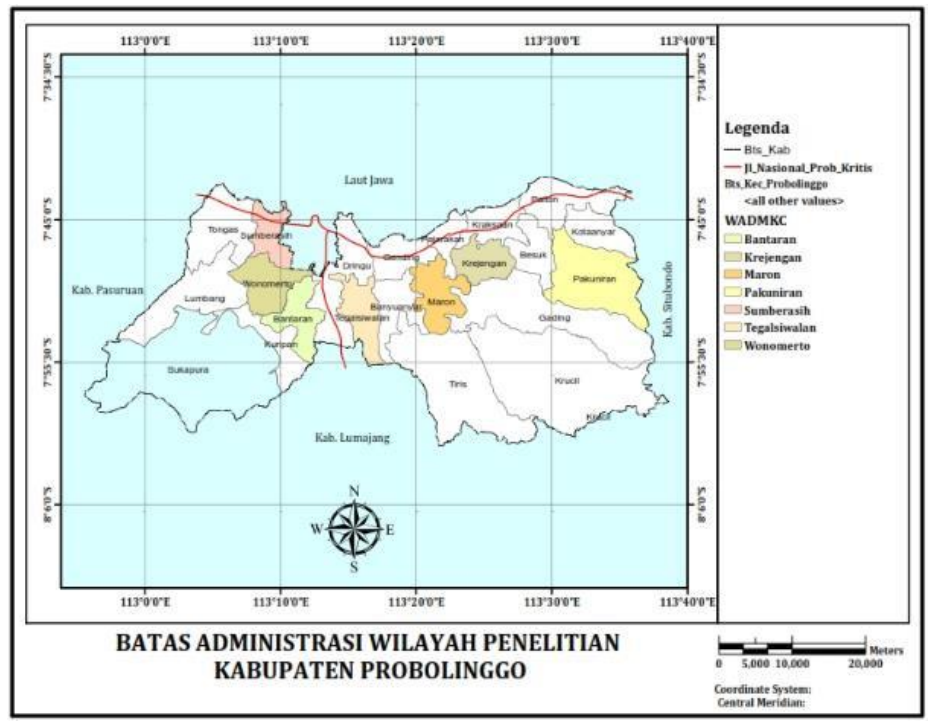

Gambar 1. Kolasi daerah penelitian status kektritisan lahan di Kabupaten Probolinggo

\section{Data Penelitian}

Data yang digunakan dalam penelitian ini adalah data primer dengan observasi lapangan di setiap kecamatan dan data sekunder yang dikumpulkan dari Sunggono (2020), meliputi : data hujan, peta tutupan lahan atau peta penggunaan lahan (Wahyuni, Mukaromah dan Urip, 2017), peta administrasi dan peta kelas lereng. Hasil analisis spasial berupa peta satuan lahan yang menjadi kajian sebaran kekritisan lahan dan titik pengamatan pengambilan sampel data biofisik. Data biofisik tanah yang diperlukan seperti tekstur tanah, permeabilitas, kelas struktur tanah, bahan organik, $\mathrm{pH}$, elektrik konduktivitas tanah,biologi tanah.

\section{Metode Penelitian}

Metode penelitian berupa identifikasi kerusakan tanah, status kekritisan lahan dan pemetaan dengan menggunakan Sistem Informasi Geografi (Aronoff, 1993), yang dibagi dalam kegiatan utama yaitu: identifikasi kerusakan tanah dan analisis spasial dengan cara tumpang susun (overlay) peta untuk pembuatan kajian keruangan administrasi, tutupan lahan, penggunaan lahan dan peta erosi dibuat dengan menghitung besarnya erosi tanah (Anasiru, 2015). Faktor kelerangan, penutupan lahan dapat digunakan secara keruangan melalui analisis ini sehingga dapat diketahui sebaran kekritisan lahan. Secara garis besar tahapan dalam analisis spasial untuk penyusunan data spasial lahan kritis terdiri dari 3 tahap yaitu: tumpang susun data spasial, editing data atribut dan analisis tabular (Renyut, Kumurur dan Karongkong, 2018).

\section{Tahap 1 : Identifikasi Kerusakan Tanah}

Identifikasi status kekritisan lahan dengan cara membandingkan antara data yang diperoleh baik dari hasil survei maupun data hasil analisis laboratorium kriteria baku kerusakan tanah berdasarkan PP No. 150 Tahun 2000, dan Peraturan Dirjen Pengendalian DAS \& Hutan Lindung Nomor P.3/PDASHL/SET/KUM.1/7/2018. Tentang Petunjuk Teknis Penyusunan Data Spasial Lahan Kritis yang tertera pada tabel 2 dan 3 .

\section{a. Penetapan status kerusakan tanah}

Penetapan status kerusakan tanah, dengan metode Skoring Frekuensi Relatif (SFR), yaitu perbandingan jumlah sampel tanah yang tergolong rusak dari parameter (fisika, kimia, biologi, kedalaman, batuan dan permeabilitas) terhadap semua sampel atau titik pengamatan, Selanjutnya setiap parameter yang telah diskor dijumlahkan, dilakukan pengkategorian status kerusakan tanah, khusunya untuk lahan kering disajikan dalam tabel 3 dan tabel 4.

\section{b. Klasifikasi potensi kerusakan tanah}

Potensi kerusakan tanah dapat diklasifikasikan menjadi 5 kelas yaitu potensi sangat rendah. rendah. sedang. tinggi. dan sangat tinggi sesuai dengan Pedoman Teknis Penyusunan Status Kerusakan Tanah untuk Produksi Biomassa dari Kementerian Lingkungan Hidup Tahun 2009. Penentuan kelas dengan cara menjumlahkan dari bobot masing-masing peta temakik dengan hasil kali nilai skor. Nilai skor yaitu nilai yang diperoleh dari hasil perkalian nilai rating dengan nilai bobot. sedang nilai rating merupakan nilai potensi dari masing-masing unsur dari peta tematik akumulasi jumlah dari bobot masing-masing peta tematik. Disajikan pada tabel 4. 
Tabel 2. Kriteria baku kerusakan tanah untuk lahan kering.

\begin{tabular}{|c|c|c|c|}
\hline No & Parameter & Metode Analisis & Ambang kritis \\
\hline 1 & Ketebalan solum & $\begin{array}{l}\text { Brunton and Tape } \\
\text { (bentang Tali) }\end{array}$ & $<20 \mathrm{~cm}$ \\
\hline 2 & Kebatuan permukaan & Pengamatan langsung & $>40 \%$ \\
\hline 3 & Komposisi fraksi pasir & Hidrometer/Pipet & $<18 \%$ koloid; Lempung / >80\% pasir kuarsatik Pasir Kasar \\
\hline 4 & Berat Volume (BV) & Gavimetrik & $>1.4 \mathrm{~g} / \mathrm{cm}^{3}$ \\
\hline 5 & Porositas total & Gavimetrik & $<30 \% ;>70 \%$ \\
\hline 6 & Derajat pelulusan air & Constant Head & $<0.7 \mathrm{~cm} / \mathrm{jam} ;>8 \mathrm{~cm} / \mathrm{jam}$ \\
\hline 7 & $\mathrm{pH}\left(\mathrm{H}_{2} \mathrm{O}\right) 1: 2.5$ & pH meter & $<4.5 ;>8.5$ \\
\hline 8 & $\begin{array}{l}\text { Daya Hantar Listrik } \\
\text { (DHL) }\end{array}$ & Konduktimeter & $>4.0 \mathrm{mS} / \mathrm{cm}$ \\
\hline 9 & Redoks & Titrasi Redoks & $<200 \mathrm{mV}$ \\
\hline 10 & Jumlah mikroba & $\begin{array}{l}\text { SPC (Standar Plate } \\
\text { Count) }\end{array}$ & $<10^{2} \mathrm{cfu} / \mathrm{g}$ tanah \\
\hline
\end{tabular}

Tabel 3. Skor kerusakan tanah berdasarkan frekuensi relative dari berbagai parameter kerusakan tanah.

Frekuensi Relatif Tanah Rusak (\%) $\quad$ Skor $\quad$ Status Kerusakan Tanah

\begin{tabular}{ccc}
\hline $0-10$ & 0 & Tidak rusak \\
$11-25$ & 1 & Rusak ringan \\
$26-50$ & 2 & Rusak sedang \\
$51-75$ & 3 & Rusak berat \\
$76-100$ & 4 & Rusak sangat berat \\
\hline
\end{tabular}

Sumber: Kementerian Negara Lingkungan Hidup (2009)

Tabel 4. Kriteria pembagian kelas potensi kerusakan tanah berdasarkan nilai skor.

\begin{tabular}{ccc}
\hline Simbol & Potensi kerusakan tanah & Skor pembobotan \\
\hline PR. I & Sangat ringan & 15 \\
PR. II & Ringan & 24 \\
PR. III & Sedang & $25-34$ \\
PR. IV & Tinggi & $35-44$ \\
PR. V & Sangat tinggi & $45-50$ \\
\hline
\end{tabular}

Sumber: Kementrian Lingkungan Hidup Tahun 2009

Tahap 2 : Penetapan dan Pemetaan Status Kekritisan Lahan

Penetapan status kekritisan lahan didasarkan pada Peraturan Dirjen Pengendalian DAS dan Hutan Lindung Nomor P.3/PDASHL/SET/KUM.1/7/2018, dengan menggabungkan skor penggunaan lahan dengan bobot $60 \%$, faktor kelerengan dan tingkat bahaya erosi dengan bobot $40 \%$. Skoring pennggunaan lahan (tutupan lahan) dilakukan dengan mengelompokkan kedalam kelas-kelas penggunaan lahan (tutupan lahan) seperti dalam tabel 5 dibawah.

Sedangkan skor erosi diperoleh dengan menghitung besarnya erosi yang diduga dengan persamaan umum kehilangan tanah, Wischmeier and Smith (1978), E = R x K x LS x CP. Erosivitas hujan dihitung dengan menggunaakan persamaan Lenvin (1978) dalam Banuwa (2013) untuk tinggi hujan bulanan dengan persamaan : $\left(\mathrm{R}_{\mathrm{b}}=2.21 \times\left(\mathrm{H}_{\mathrm{b}}\right)^{1.36}\right.$, Erodibilitas diduga dengan persamaan Wischmeier and Smith
(1978) dan (Ashari, 2013), $100 \mathrm{~K}=1,292\left[2,1 \mathrm{M}^{1,14}\left(10^{-}\right.\right.$ $4)(12-a)+3,25(b-2)+2,5(c-3)]$, nilai faktor kemiringan lereng berdasarkan kelas lereng yang dikeluarkan oleh Dirjen Pengendalian DAS dan Hutan Lindung (2018) seperti dalam tabel 6 .

Besarnya kehilangan tanah karena erosi dalam ton/ha/tahun, kemudian dibobot sesuai dengan ketentuan yang ada dalam peraturan Dirjen Pengendalian DAS dan Hutan Lindung Tahun 2018, seperti disajikan dalam Tabel 8 dibawah.

Nilai faktor CP ditentukan berdasarkan jenis penggunaan lahan dan pengelolaan lahan, dengan memodifikasi Faktor Vegetasi Penutup Tanah dan Pengelolaan Tanaman (CP) yang disampaikan dalam peraturan Dirjen Pengendalian DAS dan Hutan Lindung (2018), seperti dalam Tabel 7. 
Tabel 5. Jenis dan kelas penutupan lahan.

\begin{tabular}{|c|c|c|c|c|}
\hline No & Simbol & Penggunaan & Kelas & Skor \\
\hline 1 & Lanud & Airport & \multirow{12}{*}{1} & \multirow{12}{*}{12} \\
\hline 2 & A & Tubuh Air & & \\
\hline 3 & $\mathrm{Rw}$ & Rawa & & \\
\hline 4 & S & Savana & & \\
\hline 5 & $\mathrm{Pm} / \mathrm{Tr}$ & Pemukiman/Transmigrasi & & \\
\hline 6 & $\mathrm{Hp}$ & Hutan Lahan Kering Primer & & \\
\hline 7 & Sw & Swah & & \\
\hline 8 & $\mathrm{Tm}$ & Tambak & & \\
\hline 9 & Hmp & Hutan mangrove Primer & & \\
\hline 10 & $\mathrm{Hms}$ & Hutan Mangrove Skunder & & \\
\hline 11 & Hrp & Hutan Rawa Primer & & \\
\hline 12 & Hrs & Hutan Rawa Sekunder & & \\
\hline
\end{tabular}

\begin{tabular}{|c|c|c|c|c|}
\hline No & Simbol & Penggunaan & Kelas & Skor \\
\hline 13 & Hs & Hutan lahan Kering Sekunder & \multirow{2}{*}{2} & \multirow{2}{*}{24} \\
\hline 14 & $\mathrm{Ht}$ & Hutan Tanaman & & \\
\hline 15 & $\mathrm{Pk}$ & Perkebunan & 3 & 36 \\
\hline 16 & B & Semak/Belukar & \multirow{4}{*}{4} & \multirow{4}{*}{48} \\
\hline 17 & $\mathrm{Br}$ & Belukar Rawa & & \\
\hline 18 & $\mathrm{Pt}$ & Pertanian Lahan Kering & & \\
\hline 19 & Pc & Pertanian Lahan Kering Campuran & & \\
\hline 20 & $\mathrm{Tm}$ & Tanah Terbuka & \multirow{2}{*}{5} & \multirow{2}{*}{60} \\
\hline 21 & $\mathrm{~Tb}$ & Pertambangan & & \\
\hline 22 & Aw & Awan & \multirow{2}{*}{0} & \multirow{2}{*}{0} \\
\hline 23 & TAD & Tidak ada data & & \\
\hline
\end{tabular}

Sumber : Dirjen Pengendlian DAS dan Hutan Lindung (2018)

Tabel 6. Nilai LS berdasarkan kemiringan lereng.

\begin{tabular}{ccc}
\hline Kelas Lereng & Kemiringan lereng \% & Keterangan \\
\hline 1 & $0-8$ & Datar \\
2 & $>8-15$ & Landai \\
3 & $>15-25$ & Agak Curam \\
4 & $25-40$ & Curam \\
5 & $>40$ & Sangat Curam \\
\hline
\end{tabular}

Sumber: Dirjen Pengendlian DAS dan Hutan Lindung (2018)

Tabel 7. Nilai Faktor CP untuk berbagai aspek pengelolaan lahan.

\begin{tabular}{|c|l|c|}
\hline No. & \multicolumn{1}{|c|}{ Tata Guna Lahan } & CP \\
\hline 1 & Hutan Lahan Kering Primer & 0.001 \\
\hline 2 & Hutan lahan Kering Sekunder & 0.005 \\
\hline 3 & Pertanian Lahan Kering Campuran & 0.5 \\
\hline 4 & Sawah & 0.1 \\
\hline 5 & Airport & 1 \\
\hline 6 & Hutan Konservasi & 0.001 \\
\hline
\end{tabular}

7 Industri/Pemukiman

Sumber : Dirjen Pengendlian DAS dan Hutan Lindung (2018)

Tabel 8. Skor kelas erosi

\begin{tabular}{|c|c|c|}
\hline Erosi (ton/ha/tahun) & Keterangan & Skor \\
\hline$<15$ & Sangat Ringan & 8 \\
\hline $15-60$ & Ringan & 16 \\
\hline $60-180$ & Sedang & 24 \\
\hline $180-480$ & Berat & 32 \\
\hline$>480$ & Sangat Berat & 40 \\
\hline
\end{tabular}

Sumber : Dirjen Pengendlian DAS dan Hutan Lindung (2018) 
Tabel 9. Skor peta penutupan lahan dan erosi.

\begin{tabular}{|c|c|c|c|c|c|}
\hline Penggunaan Lahan & Kelas & Skor & Eorsi & Skor & Total Skor \\
\hline $\begin{array}{l}\text { Rawa } \\
\text { Savana } \\
\text { Hutan Lahan Kering Primer }\end{array}$ & 1 & 12 & $<15$ & 8 & 20 \\
\hline $\begin{array}{l}\text { Hutan lahan Kering Sekunder } \\
\text { Hutan Tanaman }\end{array}$ & 2 & 24 & $>15-60$ & 16 & 40 \\
\hline Perkebunan & 3 & 35 & $>60-180$ & 24 & 60 \\
\hline $\begin{array}{l}\text { Semak/Belukar } \\
\text { Pertanian Lahan Kering } \\
\text { Campuran }\end{array}$ & 4 & 48 & $>180-480$ & 32 & 80 \\
\hline $\begin{array}{l}\text { Tanah Terbuka } \\
\text { Pertambangan }\end{array}$ & 5 & 60 & $>480$ & 40 & 100 \\
\hline
\end{tabular}

Sumber : Dirjen Pengendlian DAS dan Hutan Lindung (2018)

Tabel 10. Skor kekritisan lahan.

\begin{tabular}{cc}
\hline Nomor & Skor kekritisan \\
\hline 1 & $20-36$ \\
2 & $>36-52$ \\
3 & $>52-68$ \\
4 & $>68-84$ \\
5 & $>84-100$ \\
\hline
\end{tabular}

Sumber : Dirjen Pengendlian DAS dan Hutan Lindung (2018)

Tabel 11. Skor analisa kekritisan lahan di luar kawasan hutan.

\begin{tabular}{lccccc}
\hline & \multicolumn{5}{c}{ Skor Kekritisan } \\
\cline { 2 - 5 } Lereng $(\%)$ & $0-36$ & $>36-52$ & $>52-68$ & $>68-84$ & AK \\
\hline $0-8$ & TK & TK & PK & AK & AK \\
$>8-15$ & TK & PK & AK & K & SK \\
$>15-25$ & PK & Ak & Ak & K & SK \\
$>25-40$ & PK & AK & AK & K & SK \\
$>40$ & AK & AK & AK
\end{tabular}

Sumber : Dirjen Pengendlian DAS dan Hutan Lindung (2018)

Penetapan status kekritisan lahan dilakukan dengan overlay (tumpang susun) secara bertahap peta wilayah administrasi, penggunaan lahan, peta kemiringan, dan peta erosi. Pada tabel atribut ditambahkan kolom total skor yang menjumlahkan skor penggunaan lahan dan skor erosi (Ramayanti, Yuwono,Awaluddin, 2015). Skor kektritisan lahan yang merupakan penjumlahan skor penggunaan lahan dengan bobot $60 \%$ dan skor erosi dengan bobot $40 \%$. Sesuai dengan peraturan Dirjen Pengendalian DAS dan Hutan Lindung Tahun 2018, seperti dalam tabel 9.

Untuk menilai status kekritisan dari hasil tumpang susun kedua peta tersebut didapatkan skor kekritisan lahan yang merupakan penjumlahan dari kedua skor di atas. Skor kektritisan berdasarkan kelas kektritisan seperti dalam Tabel 10 . 


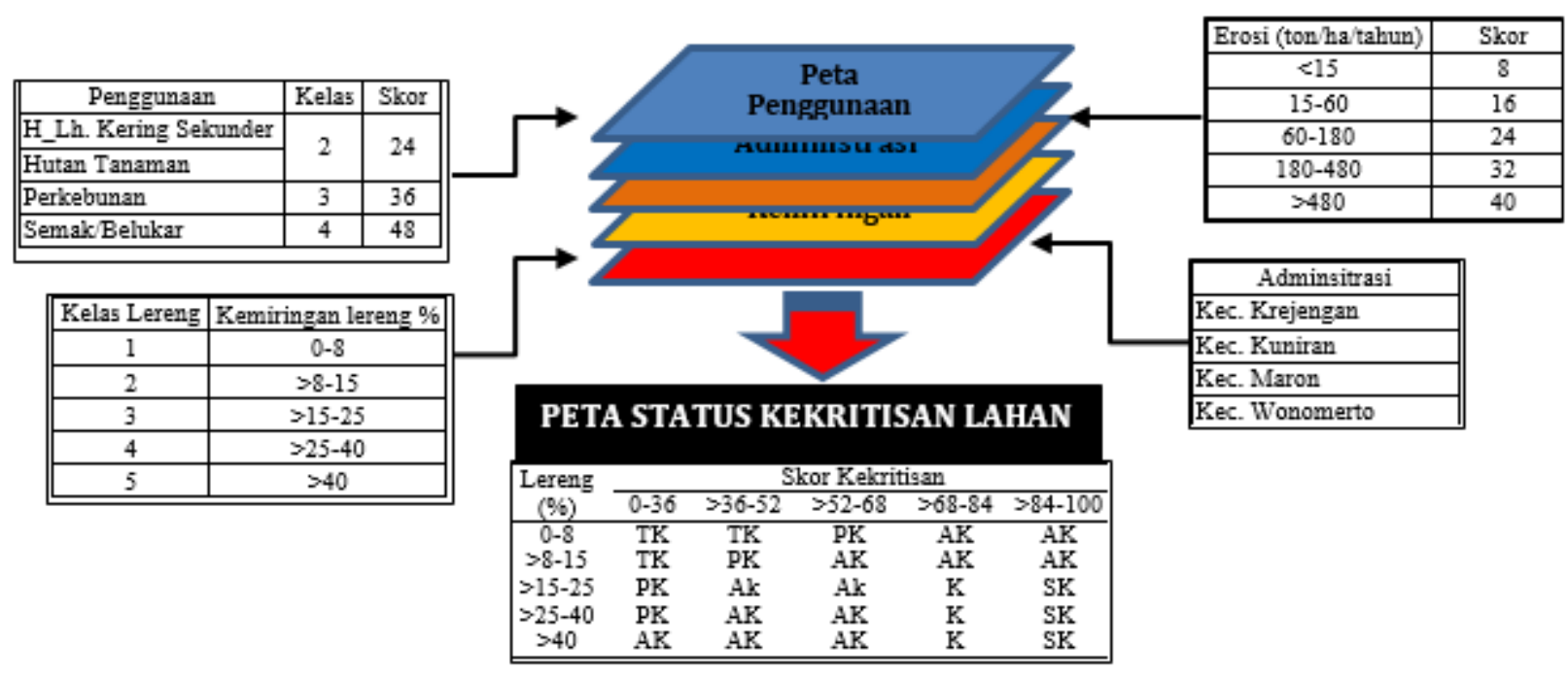

Peta status kekritis suatu wilayah ditentukan dengan mengikuti petunjuk teknis penyusunan data spasial lahan kritis Dirjen Pengendalian DAS dan Hutan Lindung Tahun 2018, dengan menumpangsusunkan peta wilayah administrasi, peta penggunaan lahan dan peta erosi. Sedangkan peta status lahan ktiris di suatu wilayah administrasi didapat dengan menumpangsusunkan peta status kekritisan wilayah administrasi dengan peta kelerengan lahan diluar wilayah kawasan hutan. Skor analisis kekritisan lahan di suatu wilayah didapatkan 5 kelas kekritisan lahan yaitu Tidak kritis (TK), Potensial Kritis (PK), Agak Kritis (AK), Kritis (K), dan Sangat Kritis (SK), berdasarkan skoring status kekritisan lahan dan kemiringan medan. Kombinasi untuk mendapatkan status kekritisan lahan didasarkan pada Tabel 11.

\section{Tumpangsusun Data Spasial}

Aplikasi Sistem Informasi Geogarfik dalam penelitian ini diarahkan dalam penyusunan basis data dan analisis data (Aronoff, 1993). Data spasial yang dikumpulkan disusun dalam layer-layer sesuai dengan kelompok data. Sedangkan data yang bersifat tabuler ditabelkan sesuai dengan kelompok spasialnya . Analisis spasial dengan tumpang susun dilakukan pada layer-layer untuk mendapatkan daerah baru yang memenuhi kriteria yang ditetapkan. Layer data kelerangan, penutupan lahan. penggunaan lahan, dan manajemen menggunkan analisis keruangan untuk mendapatkan daerah baru yang memnuhi kriteria kekritisan lahan. Secara garis besar tahapan dalam analisis spasial untuk penyusunan data spasial lahan kritis terdiri dari 3 tahap yaitu : tumpeng susun data spasial, editing data atribut dan analisis tabular (Raharjo dan Ikhsan, 2015).

Menggunakan software ArGIS 10.6. ArMap dapat dilakukan tupang susun dengan mudah. Tools tambahan yang disediakan ArGIS 10.6 yaitu Geoprocessing memudahkan mengintegrasikan data-data spasial dengan fasilitas gabung. potong. membentuk ulang. intersect. Proses tumpang susun diawali dengan layer penutupan lahan dengan kelas kemiringan lereng kemudian hasilnya ditumpangsusunkan ulang dengan layer erosi dan seterusnya untuk layer layer yang lain.

\section{Editing Data Atribut}

Mengedit data atribut secara umum adalah menambah kolom (field) baru pada atribut layer hasil tumpang susun. menjumlahkan semua skor kriteria lahan kritis dan memasukkannya kedalam kolom baru yang telah dibuat. Penjumlahan seluruh skor parameter lahan kritis menggunakan persamaan : $(60 \% *$ Skor Penutupan lahan $)+$ (40\%*Skor Erosi). Untuk menampung hasil penjumlahan dalam Field Skor_Tot dan field Klas_Kritis. Field Skor_Tot adalah field yang akan diisi dengan jumlah seluruh skor kriteria lahan kritis pada suatu unit analisis (poligon hasil tumpang susun). sedangkan Klas_Kritis adalah field yang akan diisi dengan klasifikasi lahan kritis hasil analisis tabular (Raharjo dan Ikhsan, 2015).

\section{Analisis Tabular}

Hasil editing data atribut khususnya hasil penjumlahan skor parameter kekritisan lahan. selanjutnya dianalisis untuk mengklasifikasikan tingkat kekritisan lahan pada setiap layer baru (hasil tumpang susun) beberapa parameter kekritisan lahan). Langkah yang dilakukan untuk menentukan lahan yang yang termasuk kategori Tidak kritis, Potensial kritis, Agak Kritis, Kritis, dan Sangat Kritis. adalah dengan melakukan query (menggunakan query buider) dengan formula query ([Skor_Tot] $>84 \&$ [slope] $>25$ ) untuk status sangat kritis dan formula query ([Skor_Tot] $>64 \&$ [slope] >15) untuk status kritis, formula query ([Skor_Tot] $>52 \&$ [slope] $>8$ ) untuk status agak kritis, formula query ([Skor_Tot] $>36 \&$ [slope] $>8$ ) untuk status potensial kritis dan formula query ([Skor_Tot] $<36 \&$ [slope] $<8$ ) untuk status tidak kritis. 


\section{HASIL DAN PEMBAHASAN}

\section{Karakteristik umum lokasi penelitian}

Karakteristik lahan yang meliputi jenis tanah, elevasi, penggunaan lahan, relief, lereng dan drainase dapat dilihat pada tabel 12. Jenis tanah yang ada di 7 kecataman bervariasi yaitu Entisol, Inceptisol, Ultisol, Oxisol, Alfisol.

\section{Identifikasi Kerusakan Tanah}

Berdasarkan hasil pengamatan lapangan dan hasil analisis tanah di laboratorium. selanjutnya setiap parameter dilakukan identifikasi kerusakan lahan dengan cara membandingkan dengan kriteria baku kerusakan tanah berdasarkan PP No. 150 Tahun 2000.

Hasil identifikasi parameter yang menyebabkan kerusakan tanah di wilayah 7 kecamatan masing-masing berbeda-beda. Jenis parameter tersebut meliputi komposisi fraksi. derajat pelulusan air dan redoks. Jumlah parameter yang menyebabkan kerusakan tanah mempengaruhi tingkat kerusakan tanah, seperti disajikan dalam tabel 13,14, 15, 16, 17, 18, dan 19.

\section{Penetapan Status kerusakan tanah}

Penetapan status kerusakan tanah, dengan metode Skoring Frekuensi Relatif (SFR), yaitu perbandingan jumlah sampel tanah yang tergolong rusak dari parameter (fisika, kimia, biologi, kedalaman, batuan dan permeabilitas) terhadap semua sampel atau titik pengamatan. Selanjutnya skoring dilakukan dengan menghitung frekuensi relatif kerusakan tanah. Pengkategorian status kerusakan tanah. khusunsya untuk lahan kering berdasarkan kriteria pada tabel 20.

Tabel 12. Karakteristik umum lahan.

\begin{tabular}{|c|c|c|c|c|c|c|c|c|c|}
\hline $\mathrm{Kec}$ & Jenis Tanah & $\begin{array}{c}\text { Elevasi } \\
(\mathrm{mdpl})\end{array}$ & Sawah (ha) & Tegal (ha) & $\begin{array}{l}\text { Hutan } \\
\text { (ha) }\end{array}$ & $\begin{array}{l}\text { Non Hutan } \\
\text { (ha) }\end{array}$ & Relief & $\begin{array}{c}\text { Lereng } \\
(\%)\end{array}$ & Drainase \\
\hline Sumber Asih & Inceptisol Pasir Pantai & $250-405$ & 1668.50 & 635.40 & 0 & 431.6 & berombak & $3-5$ & $\mathrm{sec}$ \\
\hline Wonomerto & Oxisol & $300-410$ & 1.181 .81 & 2.345 .27 & 310.50 & 660.91 & Agak berombak & $5-8$ & $\mathrm{Ce}$ \\
\hline Bantaran & Oxisol & $260-425$ & 802.92 & 2.546 .02 & 325.00 & 627.89 & Agak berombak & $3-5$ & sedang \\
\hline Tegal Siwalan & Ultisol dan Oxisol & $425-610$ & 1160 & 2.392 .11 & 0 & 621.50 & Bergelombang & $8-15$ & Sedang \\
\hline Maron & Ultisol dan Oxisol & $370-415$ & 2870.60 & 879.70 & 424.0 & 964.30 & Agak berombak & $5-8$ & Sedang \\
\hline Krejengan & Ultisol dan Oxisol & $400-540$ & 2.343 .06 & 509.12 & 30.00 & 133.58 & bergelombang & $5-8$ & Lambat \\
\hline Pakuniran & Alfisol dan Inceptisol & $410-620$ & 1.787 .20 & 2.746 .20 & 5627.30 & 1307.80 & Bergelombang & $15-30$ & Lambat \\
\hline
\end{tabular}

Tabel 13. Status tiap parameter kerusakan tanah di kecamatan sumber asih.

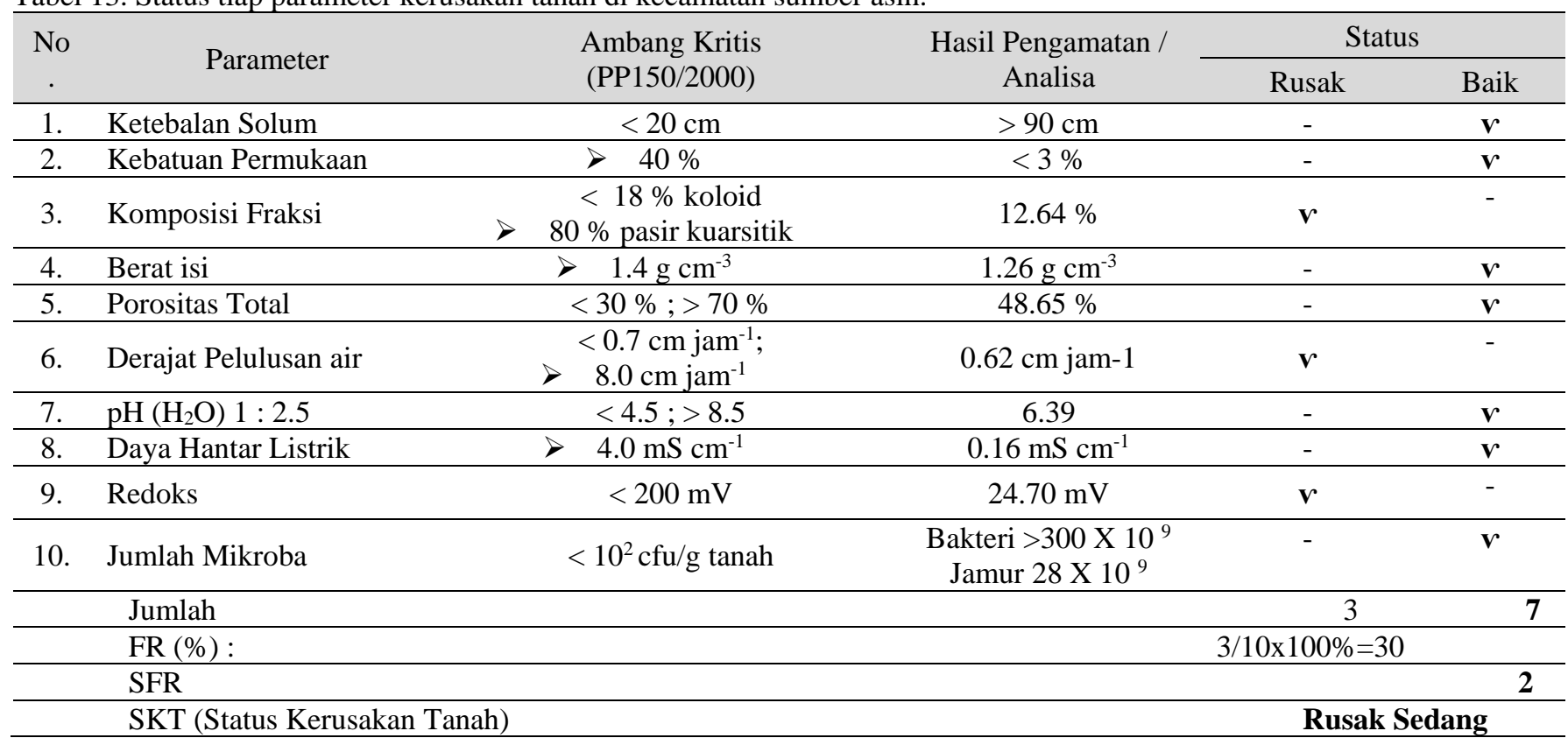

Sumber : Analisis Laboratorium 
Tabel 14. Status tiap parameter kerusakan tanah di kecamatan wonomerto

\begin{tabular}{|c|c|c|c|c|c|}
\hline \multirow{2}{*}{ No. } & \multirow{2}{*}{ Parameter } & \multirow{2}{*}{$\begin{array}{l}\text { Ambang Kritis } \\
(\mathrm{PP} 150 / 2000)\end{array}$} & \multirow{2}{*}{$\begin{array}{c}\text { Hasil Pengamatan / } \\
\text { Analisa }\end{array}$} & \multicolumn{2}{|l|}{ Status } \\
\hline & & & & Rusak & Baik \\
\hline 1. & Ketebalan Solum & $<20 \mathrm{~cm}$ & $>80 \mathrm{~cm}$ & - & $\mathbf{r}$ \\
\hline 2. & Kebatuan Permukaan & $>40 \%$ & $2 \%$ & - & $\mathbf{r}$ \\
\hline 3. & Komposisi Fraksi & $\begin{array}{c}<18 \% \text { koloid } \\
80 \% \text { pasir kuarsitik }\end{array}$ & $22 \%$ & - & $\mathbf{r}$ \\
\hline 4. & Berat isi & $>1.4 \mathrm{~g} \mathrm{~cm}^{-3}$ & $1.18 \mathrm{~g} \mathrm{~cm}^{-3}$ & - & $\mathbf{r}$ \\
\hline 5. & Porositas Total & $<30 \% ;>70 \%$ & $44.9 \%$ & - & $\mathbf{r}$ \\
\hline 6. & Derajat Pelulusan air & $\begin{array}{r}\quad<0.7 \mathrm{~cm} \mathrm{jam}^{-1} \\
>\quad 8.0 \mathrm{~cm} \mathrm{jam}^{-1} \\
\end{array}$ & $0.11 \mathrm{~cm} \mathrm{jam}-1$ & $\mathbf{r}$ & - \\
\hline 7. & $\mathrm{pH}\left(\mathrm{H}_{2} \mathrm{O}\right) 1: 2.5$ & $<4.5 ;>8.5$ & 5.50 & - & $r$ \\
\hline 8. & Daya Hantar Listrik & $>4.0 \mathrm{mS} \mathrm{cm}^{-1}$ & $0.17 \mathrm{mS} \mathrm{cm}^{-1}$ & - & $\mathbf{r}$ \\
\hline 9. & Redoks & $<200 \mathrm{mV}$ & $29.70 \mathrm{mV}$ & $\mathbf{v}$ & - \\
\hline 10. & Jumlah Mikroba & $<10^{2} \mathrm{cfu} / \mathrm{g}$ tanah & $\begin{array}{c}\text { Bakteri }>300 \times 10^{7} \\
\text { Jamur } 2 \times 10^{4}\end{array}$ & - & $\mathbf{r}$ \\
\hline & Jumlah & & & 2 & 8 \\
\hline & FR $(\%):$ & & & $2 / 10 \times 100 \%=20$ & \\
\hline & SFR & & & & 1 \\
\hline & SKT (Status Kerusal & anah) & & ringan & \\
\hline
\end{tabular}

Sumber : Analisis Laboratorium

Tabel 15. Status tiap parameter kerusakan tanah di kecamatan bantaran.

\begin{tabular}{|c|c|c|c|c|c|}
\hline \multirow{2}{*}{ No. } & \multirow{2}{*}{ Parameter } & \multirow{2}{*}{$\begin{array}{l}\text { Ambang Kritis } \\
\text { (PP150/2000) }\end{array}$} & \multirow{2}{*}{$\begin{array}{c}\text { Hasil Pengamatan / } \\
\text { Analisa }\end{array}$} & \multicolumn{2}{|c|}{ Status } \\
\hline & & & & Rusak & Baik \\
\hline 1. & Ketebalan Solum & $<20 \mathrm{~cm}$ & $>90 \mathrm{~cm}$ & - & $r$ \\
\hline 2. & $\begin{array}{l}\text { Kebatuan } \\
\text { Permukaan }\end{array}$ & $>40 \%$ & $<5 \%$ & - & $r$ \\
\hline 3. & Komposisi Fraksi & $\begin{array}{c}<18 \% \text { koloid } \\
<\quad 80 \% \text { pasir kuarsitik } \\
\end{array}$ & $11 \%$ & $\mathbf{r}$ & - \\
\hline 4. & Berat isi & $>1.4 \mathrm{~g} \mathrm{~cm}^{-3}$ & $1.03 \mathrm{~g} \mathrm{~cm}^{-3}$ & - & $\mathbf{r}$ \\
\hline 5. & Porositas Total & $<30 \% ;>70 \%$ & $62.28 \%$ & - & $\mathbf{r}$ \\
\hline 6. & $\begin{array}{l}\text { Derajat Pelulusan } \\
\text { air }\end{array}$ & $\begin{array}{c}<0.7 \mathrm{~cm} \mathrm{jam}^{-1} \\
>\quad 8.0 \mathrm{~cm} \mathrm{jam}^{-1}\end{array}$ & $0.41 \mathrm{~cm}$ jam-1 & $\mathbf{r}$ & - \\
\hline 7. & $\mathrm{pH}\left(\mathrm{H}_{2} \mathrm{O}\right) 1: 2.5$ & $<4.5 ;>8.5$ & 5.93 & - & $r$ \\
\hline 8. & $\begin{array}{l}\text { Daya Hantar } \\
\text { Listrik }\end{array}$ & $>\quad 4.0 \mathrm{mS} \mathrm{cm}^{-1}$ & $0.06 \mathrm{mS} \mathrm{cm}^{-1}$ & - & $r$ \\
\hline 9. & Redoks & $<200 \mathrm{mV}$ & $14.50 \mathrm{mV}$ & $\mathbf{r}$ & - \\
\hline 10 & Jumlah Mikroba & $<10^{2} \mathrm{cfu} / \mathrm{g}$ tanah & $\begin{array}{c}\text { Bakteri }>300 \times 10^{9} \\
\text { Jamur } 2 \times 10^{9}\end{array}$ & - & $r$ \\
\hline & Jumlah & & & 3 & 7 \\
\hline & FR $(\%):$ & & & $3 / 10 \times 100 \%=30$ & \\
\hline & SFR & & & & 2 \\
\hline & SKT (Status Ker & sakan Tanah) & & Rusak Sedang & \\
\hline
\end{tabular}

Sumber : Analisis Laboratorium 
Tabel 16. Status tiap parameter kerusakan tanah di kecamatan tegal siwalan.

\begin{tabular}{|c|c|c|c|c|c|}
\hline \multirow{2}{*}{ No. } & \multirow{2}{*}{ Parameter } & \multirow{2}{*}{$\begin{array}{l}\text { Ambang Kritis } \\
\text { (PP150/2000) }\end{array}$} & \multirow{2}{*}{$\begin{array}{c}\text { Hasil Pengamatan / } \\
\text { Analisa }\end{array}$} & \multicolumn{2}{|c|}{ Status } \\
\hline & & & & Rusak & Baik \\
\hline 1. & Ketebalan Solum & $<20 \mathrm{~cm}$ & $>90 \mathrm{~cm}$ & - & $\mathbf{r}$ \\
\hline 2. & $\begin{array}{l}\text { Kebatuan } \\
\text { Permukaan }\end{array}$ & $>40 \%$ & $<5 \%$ & - & $\mathbf{r}$ \\
\hline 3. & Komposisi Fraksi & $\begin{array}{c}<18 \% \text { koloid } \\
. \quad 80 \% \text { pasir kuarsitik } \\
\end{array}$ & $26 \%$ & - & $\mathbf{r}$ \\
\hline 4. & Berat isi & $>1.4 \mathrm{~g} \mathrm{~cm}^{-3}$ & $1.44 \mathrm{~g} \mathrm{~cm}^{-3}$ & $\mathbf{r}$ & - \\
\hline 5. & Porositas Total & $<30 \% ;>70 \%$ & $48.57 \%$ & - & $\mathbf{r}$ \\
\hline 6. & $\begin{array}{l}\text { Derajat Pelulusan } \\
\text { air }\end{array}$ & $\begin{array}{r}\quad<0.7 \mathrm{~cm} \mathrm{jam}^{-1} ; \\
>\quad 8.0 \mathrm{~cm} \mathrm{jam}^{-1} \\
\end{array}$ & $0.09 \mathrm{~cm}$ jam- 1 & $\mathbf{r}$ & - \\
\hline 7. & $\mathrm{pH}\left(\mathrm{H}_{2} \mathrm{O}\right) 1: 2.5$ & $<4.5 ;>8.5$ & 5.57 & - & $\mathbf{r}$ \\
\hline 8. & $\begin{array}{l}\text { Daya Hantar } \\
\text { Listrik }\end{array}$ & $>\quad 4.0 \mathrm{mS} \mathrm{cm}^{-1}$ & $0.18 \mathrm{mS} \mathrm{cm}^{-1}$ & - & $\mathbf{r}$ \\
\hline 9. & Redoks & $<200 \mathrm{mV}$ & $88.0 \mathrm{mV}$ & $\mathbf{r}$ & \\
\hline 10. & Jumlah Mikroba & $<10^{2} \mathrm{cfu} / \mathrm{g}$ tanah & $\begin{array}{c}\text { Bakteri }>100 \times 10^{9} \\
\text { Jamur } 1 \text { X } 10^{9}\end{array}$ & - & $\mathbf{r}$ \\
\hline & Jumlah & & & 3 & 7 \\
\hline & FR $(\%):$ & & & $3 / 10 \times 100$ & \\
\hline & SFR & & & & 2 \\
\hline & SKT (Status Ker & sakan Tanah) & & & \\
\hline
\end{tabular}

Sumber : Analisis Laboratorium

Tabel 17. Status tiap parameter kerusakan tanah di kecamatan maron.

\begin{tabular}{|c|c|c|c|c|c|}
\hline \multirow{2}{*}{ No. } & \multirow{2}{*}{ Parameter } & \multirow{2}{*}{$\begin{array}{l}\text { Ambang Kritis } \\
(\mathrm{PP} 150 / 2000)\end{array}$} & \multirow{2}{*}{$\begin{array}{c}\text { Hasil Pengamatan / } \\
\text { Analisa }\end{array}$} & \multicolumn{2}{|l|}{ Status } \\
\hline & & & & Rusak & Baik \\
\hline 1. & Ketebalan Solum & $<20 \mathrm{~cm}$ & $50 \mathrm{~cm}$ & - & $\mathbf{r}$ \\
\hline 2. & Kebatuan Permukaan & $>40 \%$ & $<5 \%$ & - & $r$ \\
\hline 3. & Komposisi Fraksi & $\begin{array}{c}<18 \% \text { koloid } \\
80 \% \text { pasir kuarsitik }\end{array}$ & $24 \%$ & - & $\mathbf{v}$ \\
\hline 4. & Berat isi & $>1.4 \mathrm{~g} \mathrm{~cm}^{-3}$ & $1.27 \mathrm{~g} \mathrm{~cm}^{-3}$ & - & $r$ \\
\hline 5. & Porositas Total & $<30 \% ;>70 \%$ & $49.45 \%$ & - & $r$ \\
\hline 6. & Derajat Pelulusan air & $\begin{array}{r}\quad<0.7 \mathrm{~cm} \mathrm{jam}^{-1} ; \\
>\quad 8.0 \mathrm{~cm} \mathrm{jam}^{-1}\end{array}$ & $0.35 \mathrm{~cm}$ jam-1 & $\mathbf{v}$ & - \\
\hline 7. & $\mathrm{pH}\left(\mathrm{H}_{2} \mathrm{O}\right) 1: 2.5$ & $<4.5 ;>8.5$ & 6.77 & - & $r$ \\
\hline 8. & Daya Hantar Listrik & $>4.0 \mathrm{mS} \mathrm{cm}^{-1}$ & $0.20 \mathrm{mS} \mathrm{cm}^{-1}$ & - & $r$ \\
\hline 9. & Redoks & $<200 \mathrm{mV}$ & $24.10 \mathrm{mV}$ & $\mathbf{r}$ & - \\
\hline 10. & Jumlah Mikroba & $<10^{2} \mathrm{cfu} / \mathrm{g}$ tanah & $\begin{array}{c}\text { Bakteri }>300 \times 10^{9} \\
\text { Jamur } 2 \times 10^{9}\end{array}$ & - & $\mathbf{r}$ \\
\hline & Jumlah & & & 2 & 7 \\
\hline & FR $(\%):$ & & & $2 / 10 \times 100 \%=20$ & \\
\hline & SFR & & & & 1 \\
\hline & SKT (Status Kerusal & n Tanah) & & Rusak ri & \\
\hline
\end{tabular}


Tabel 18. Status tiap parameter kerusakan tanah di kecamatan krejengan.

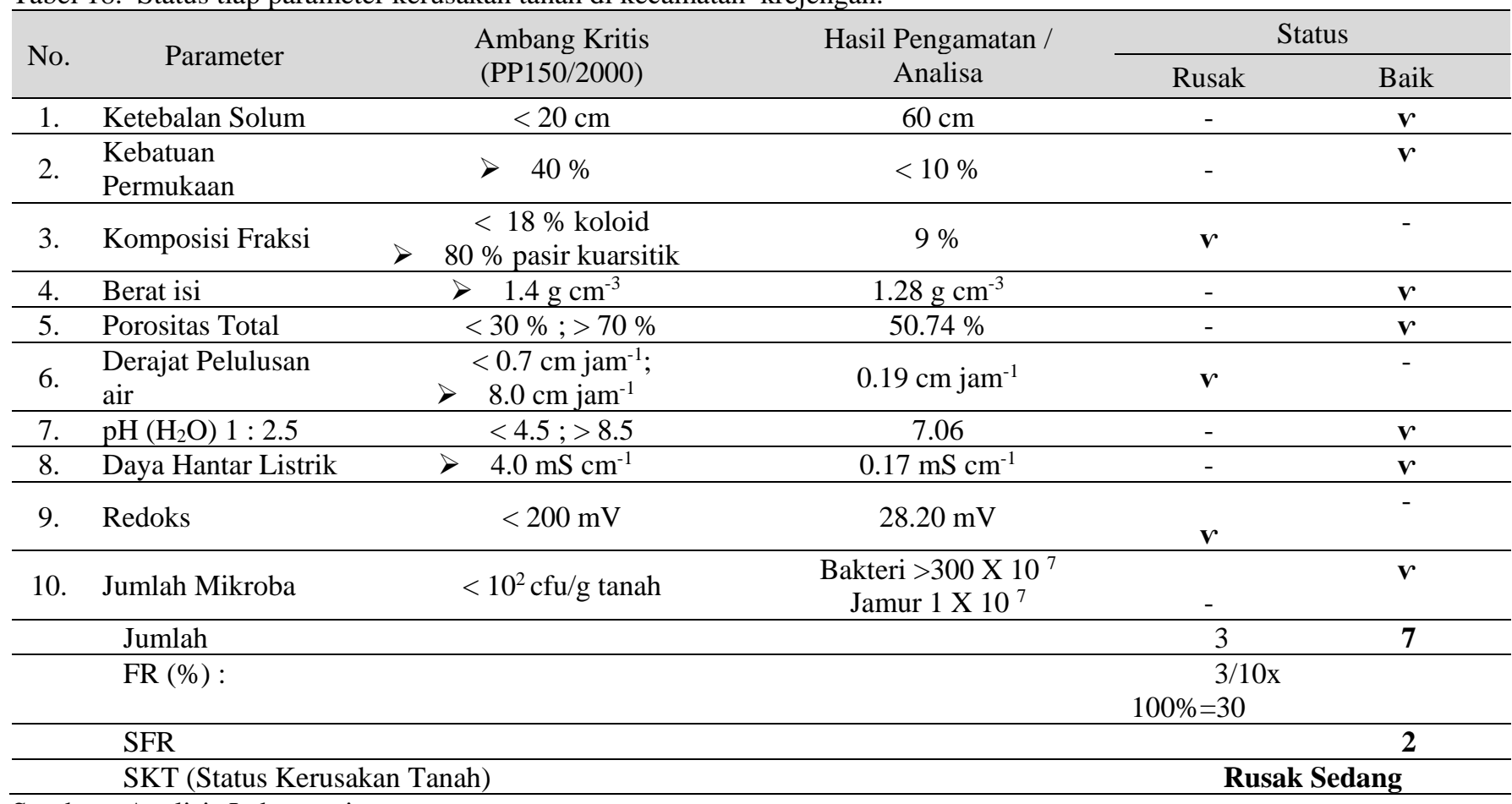

Sumber : Analisis Laboratorium

Tabel 19. Status tiap parameter kerusakan tanah di kecamatan pakuniran.

\begin{tabular}{|c|c|c|c|c|c|}
\hline \multirow{2}{*}{ No. } & \multirow{2}{*}{ Parameter } & \multirow{2}{*}{$\begin{array}{l}\text { Ambang Kritis } \\
\text { (PP150/2000) }\end{array}$} & \multirow{2}{*}{$\begin{array}{l}\text { Hasil Pengamatan / } \\
\text { Analisa }\end{array}$} & \multicolumn{2}{|c|}{ Status } \\
\hline & & & & Rusak & Baik \\
\hline 1. & Ketebalan Solum & $<20 \mathrm{~cm}$ & $75 \mathrm{~cm}$ & - & $\mathbf{v}$ \\
\hline 2. & $\begin{array}{l}\text { Kebatuan } \\
\text { Permukaan }\end{array}$ & $>40 \%$ & $<10 \%$ & - & $\mathbf{r}$ \\
\hline 3. & Komposisi Fraksi & $\begin{array}{c}<18 \% \text { koloid } \\
>\quad 80 \% \text { pasir kuarsitik } \\
\end{array}$ & $12 \%$ & $\mathbf{r}$ & - \\
\hline 4. & Berat isi & $>1.4 \mathrm{~g} \mathrm{~cm}^{-3}$ & $1.30 \mathrm{~g} \mathrm{~cm}^{-3}$ & - & $\mathbf{r}$ \\
\hline 5. & Porositas Total & $<30 \% ;>70 \%$ & $48.34 \%$ & - & $\mathbf{r}$ \\
\hline 6. & $\begin{array}{l}\text { Derajat Pelulusan } \\
\text { air }\end{array}$ & $\begin{array}{r}<0.7 \mathrm{~cm} \mathrm{jam}^{-1} \\
>\quad 8.0 \mathrm{~cm} \mathrm{jam}^{-1} \\
\end{array}$ & $0.14 \mathrm{~cm} \mathrm{jam}^{-1}$ & $\mathbf{r}$ & - \\
\hline 7. & $\mathrm{pH}\left(\mathrm{H}_{2} \mathrm{O}\right) 1: 2.5$ & $<4.5 ;>8.5$ & 6.42 & - & $\mathbf{r}$ \\
\hline 8. & Daya Hantar Listrik & $>4.0 \mathrm{mS} \mathrm{cm}^{-1}$ & $0.19 \mathrm{mS} \mathrm{cm}^{-1}$ & - & $\mathbf{r}$ \\
\hline 9. & Redoks & $<200 \mathrm{mV}$ & $33.70 \mathrm{mV}$ & $\mathbf{r}$ & - \\
\hline 10. & Jumlah Mikroba & $<10^{2} \mathrm{cfu} / \mathrm{g}$ tanah & $\begin{array}{c}\text { Bakteri }>300 \times 10^{7} \\
\text { Jamur } 3 \times 10^{7}\end{array}$ & - & $\mathbf{r}$ \\
\hline & Jumlah & & & 3 & 7 \\
\hline & FR $(\%):$ & & & $3 / 10 \times 10$ & \\
\hline & SFR & & & & 2 \\
\hline & SKT (Status Kerus & n Tanah) & & Rus & \\
\hline
\end{tabular}

Sumber : Analisis Laboratorium 
Tabel 20. Status kerusakan tanah dan skor frekuansi relatif. Tiap-tiap kecamatan

\begin{tabular}{llcccl}
\hline No & \multicolumn{1}{c}{ Kecamatan } & $\begin{array}{c}\text { Frekuensi Relatif } \\
(\text { FF })(\%)\end{array}$ & $\begin{array}{c}\text { Skor Frekuaensi } \\
\text { Relatif (SFR) }\end{array}$ & $\begin{array}{c}\text { Status Kerusakan Tanah } \\
\text { Simbol }\end{array}$ \\
\hline 1 & Sumber Asih & 30 & 2 & Rusak sedang & R.II-f.p.r \\
2 & Wonomerto & 20 & 1 & Rusak ringan & R.I-p.r \\
3 & Bantaran & 30 & 2 & Rusak sedang & R.II-f.p.r \\
4 & Tegal Siwalan & 30 & 2 & Rusak sedang & R.II-b.p.r \\
5 & Maron & 20 & 1 & Rusak ringan & R.II-p.r \\
6 & Krejengan & 30 & 2 & Rusak sedang & R.II-f.p.r \\
7 & Pakuniran & 30 & 2 & Rusak sedang & R.II-f.p.r \\
\hline
\end{tabular}

Tabel 21. Kemiringan lahan

\begin{tabular}{|c|c|c|c|c|}
\hline No & Kecamatan & Kelerengan (\%) & Kls. Lereng & Luas (ha) \\
\hline \multirow[t]{3}{*}{1} & Pakuniran & $0-8$ & Datar & $1.102,54$ \\
\hline & & $8-15$ & Landai & $1.710,25$ \\
\hline & & $25-40$ & Curam & $21.910,05$ \\
\hline 2 & Krejengan & $0-8$ & Datar & 3.903 .60 \\
\hline \multirow[t]{2}{*}{3} & Maron & $0-8$ & Datar & $3.339,82$ \\
\hline & & $8-15$ & Landai & $1.801,72$ \\
\hline \multirow[t]{2}{*}{4} & Tegalsiwalan & $0-8$ & Datar & $1.596,51$ \\
\hline & & $8-15$ & Landai & $2.895,93$ \\
\hline \multirow[t]{2}{*}{5} & Bantaran & $0-8$ & Datar & $2,221,42$ \\
\hline & & $8-15$ & Landai & $2.184,14$ \\
\hline \multirow[t]{2}{*}{6} & Wonomerto & $0-8$ & Datar & $1.091,94$ \\
\hline & & $8-15$ & Landai & $3.709,40$ \\
\hline \multirow[t]{2}{*}{7} & Sumberasih & $0-8$ & Datar & 2732,38 \\
\hline & & $8-15$ & Landai & 513,29 \\
\hline
\end{tabular}

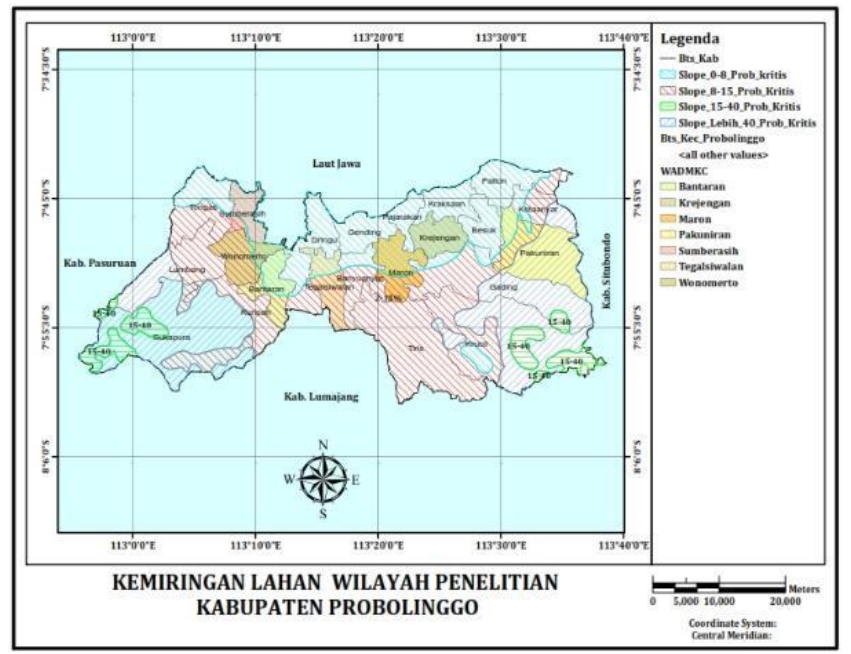

Gambar 2. Sebaran Kemiringan Lahan didaerah Penelitian

Berdasarkan penetapan status kerusakan tanah terhadap setiap parameter kerusakan tanah dan menentukan status kerusakan tanah dengan menentukan SFR. Ada 2 kecamatan SFR yang nilainya 1 dengan status kerusakan tanah rusak ringan yaitu kecamatan Wonomerto dan Maron. Sedangkan 5 kecamatan lainnya yaitu Sumber Asih,
Bantaran, Tegal Siwalan, Krejengan dan Pakuniran,dengan nilai SFR 2 dengan status kerusakan tanah rusak sedang. Sedangkan parameter yang mengakibatkan kerusakan tanah ringan di kecamatan Wonomerto dan Maron adalah derajat pelulusam air (p) dan redoks (r). 
Tabel 22. Persentase dan luasan tutupan lahan di 7 kecamatan daerah penelitian.

\begin{tabular}{llrr}
\hline WAdmKc & Jenis Tutupan & \multicolumn{1}{c}{ Luas } & Persentase \\
\hline Sumberasih & Sawah & 2420.47 & 78.17 \\
& Tambak & 110.99 & 3.58 \\
& Pemukiman & 564.94 & 18.25 \\
\hline Wonomerto & Sawah & 4083.99 & 85.06 \\
& Tegal & 64.66 & 1.35 \\
& Pemukiman & 88.25 & 1.84 \\
& Hutan & 564.44 & 11.76 \\
\hline Bantaran & Sawah & 3694.21 & 83.85 \\
& Tegal & 89.92 & 2.04 \\
& & & \\
& Pemukiman & 165.37 & 3.75 \\
& Hutan & 456.06 & 10.35 \\
\hline Tegalsiwalan & Pemukiman & 151.90 & 3.38 \\
& Sawah & 4244.35 & 94.48 \\
\hline
\end{tabular}

\begin{tabular}{llrr}
\hline WAdmKc & Jenis Tutupan & \multicolumn{1}{c}{ Luas } & Persentase \\
\hline Tegalsiwalan & Hutan & 96.19 & 2.14 \\
\hline Maron & Sawah & 4253.78 & 82.73 \\
& Pemukiman & 557.07 & 10.83 \\
& Hutan & 330.69 & 6.43 \\
\hline Krejengan & Sawah & 3103.17 & 79.50 \\
& Pemukiman & 408.53 & 10.47 \\
& Hutan & 391.90 & 10.04 \\
\hline Pakuniran & Sawah & 1432.36 & 14.28 \\
& Hutan & 6980.74 & 69.62 \\
& Lahan & & \\
& Kosong & 825.67 & 8.23 \\
& Tegal & 436.01 & 4.35 \\
& Pemukiman & 352.75 & 3.52 \\
\hline
\end{tabular}

Sumber : Hasil analisis tutupan lahan

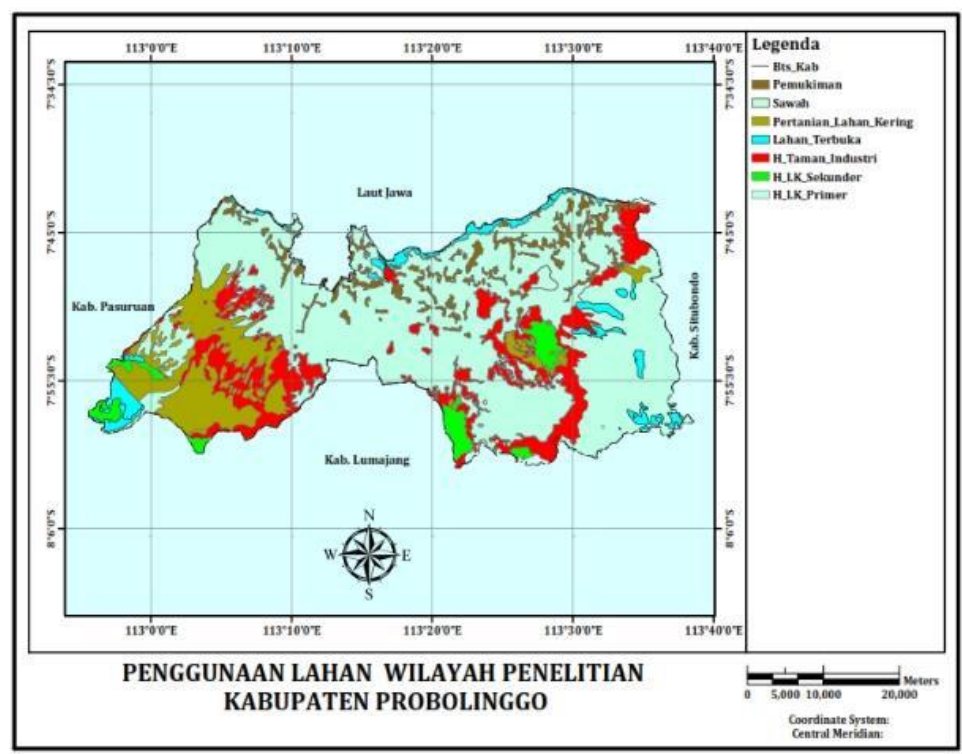

Gambar 3. Sebaran tutupan lahan daerah penelitian.

Tabel 23. Besarnya erosi tanah di daerah penelitian.

\begin{tabular}{llrr}
\hline WAdmKc & Penggunaan & \multicolumn{1}{c}{ Erosi } & Persentase \\
\hline \multirow{4}{*}{ Sumberasih } & Ton/ha/th & \\
& Sawah & 320.94 & 18.77 \\
& Tambak & 22.84 & 1.34 \\
& Pemukiman & 1365.72 & 79.89 \\
\hline Wonomerto & Sawah & 2942.65 & 62.69 \\
& Pemukiman & 873.20 & 18.60 \\
& Tegal & 319.89 & 6.81 \\
& Hutan & 558.49 & 11.90 \\
\hline Bantaran & Sawah & 858.58 & 39.86 \\
& Pemukiman & 375.54 & 17.43 \\
& Tegal & 357.35 & 16.59 \\
& Hutan & 562.50 & 26.11 \\
\hline Tegalsiwalan & Sawah & 3568.11 & 61.81 \\
& Pemukiman & 2071.70 & 35.89 \\
\hline
\end{tabular}

\begin{tabular}{llrr}
\hline WAdmKc & Penggunaan & \multicolumn{1}{c}{ Erosi } & Persentase \\
\hline \multirow{4}{*}{ Tegalsiwalan } & Ton/ha/th & \\
\hline Maron & Sawah & 132.45 & 2.29 \\
& Pemukiman & 4748.96 & 13.25 \\
& Hutan & 2347.32 & 58.06 \\
\hline Krejengan & Sawah & 5206.32 & 37.39 \\
& Pemukiman & 8545.04 & 61.36 \\
& Hutan & 174.27 & 1.25 \\
\hline Pakuniran & Sawah & 422.19 & 2.55 \\
& Pemukiman & 1356.23 & 8.19 \\
& Tegal & 5518.24 & 33.33 \\
& Hutan & 638.46 & 3.86 \\
& Lhn_Terbuka & 8619.91 & 52.07 \\
\hline
\end{tabular}

Sumber : Hasil analisis 


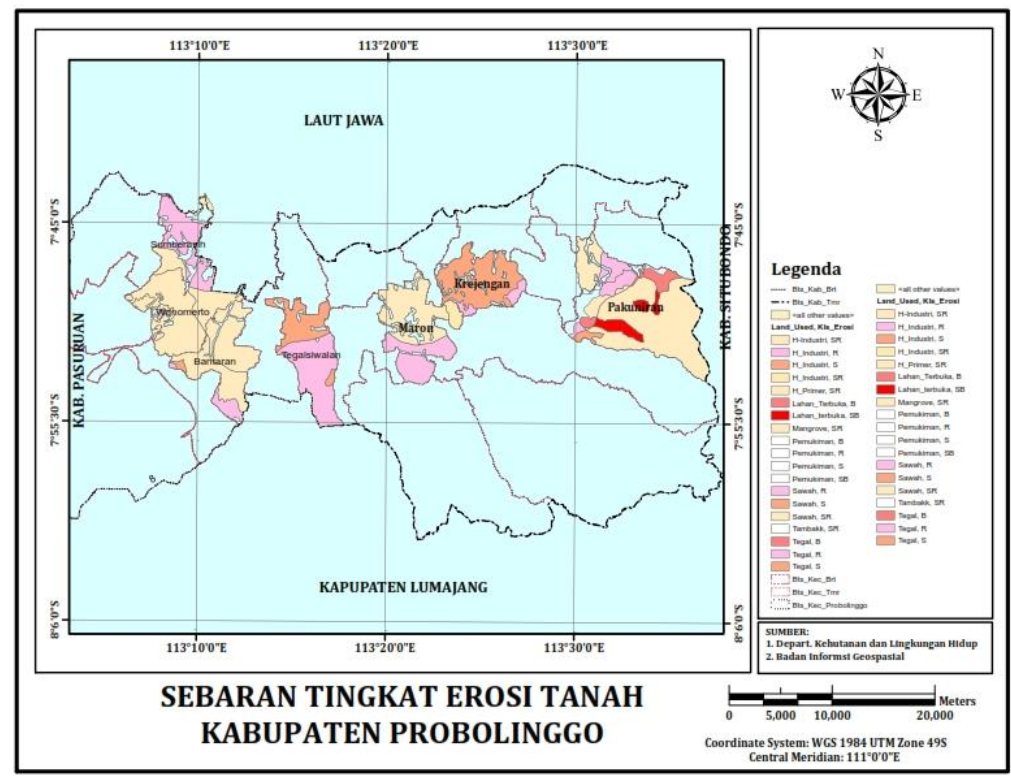

Gambar 4. Tingkat bahaya erosi di tujuh kecamatan wilayah penelitian.

Tabel 24. Sebaran Luas dan Persentase Status Lahan dengan Berbagai Penggunaan di Wilayah Penelitian

\begin{tabular}{cllrlcc}
\hline Kec & Penggunaan & Slope & \multicolumn{1}{c}{ Luas } & Jumlah & Status & $\%$ \\
\hline Sumberasih & Pemukiman & $0-8$ & 564.94 & 2732.38 & TK & 84.19 \\
& Tambak & $0-8$ & 110.99 & & TK & \\
& Mangrove & $0-8$ & 149.27 & & TK & \\
& Sawah & $0-8$ & 1907.18 & & TK & \\
\cline { 2 - 7 } Wonomerto & Sawah & $8-15$ & 513.29 & 513.29 & PK & 15.81 \\
\cline { 2 - 8 } & Pemukiman & $0-8$ & 88.25 & 1091.94 & TK & 22.74 \\
& Sawah & $0-8$ & 1003.69 & & TK & \\
\cline { 2 - 8 } & H.Industri & $8-15$ & 564.44 & 629.1 & AK & 13.10 \\
& Tegal & $8-15$ & 64.66 & & AK & \\
\cline { 2 - 8 } Bantaran & Sawah & $8-15$ & 3080.3 & 3080.3 & PK & 64.16 \\
\cline { 2 - 8 } & H.Industri & $8-15$ & 456.06 & 545.98 & AK & 12.39 \\
& Tegal & $8-15$ & 89.92 & & AK & \\
\cline { 2 - 8 } & Pemukiman & $0-8$ & 165.37 & 2221.42 & TK & 50.42 \\
& Sawah & $0-8$ & 1828.08 & & TK & \\
& Sawah & $0-8$ & 227.97 & & TK & \\
\cline { 2 - 8 } Tegalsiwalan & Sawah & $8-15$ & 1638.16 & 1638.16 & PK & 37.18 \\
\cline { 2 - 8 } & Pemukiman & $0-8$ & 151.9 & 1596.51 & TK & 35.54 \\
& Sawah & $0-8$ & 1444.61 & & TK & \\
\cline { 2 - 8 } & H. Industri & $8-15$ & 96.19 & 2895.93 & PK & 64.46 \\
& Sawah & $8-15$ & 2799.74 & & PK & \\
\hline
\end{tabular}

\begin{tabular}{clcrccc}
\hline Kec & Penggunaan & Slope & \multicolumn{1}{c}{ Luas } & Jumlah & Tingkat & $\%$ \\
\hline Maron & Pemukiman & $0-8$ & 491.71 & 3009.13 & TK & 58.53 \\
& Sawah & $0-8$ & 2517.42 & & TK & \\
\cline { 2 - 8 } & H. Industri & $0-8$ & 330.69 & 2132.41 & PK & 41.47 \\
& Pemukiman & $8-15$ & 65.36 & & PK & \\
& Sawah & $8-15$ & 1736.36 & & PK & \\
\hline Krejengan & Sawah & $0-8$ & 3103.17 & 3511.7 & TK & 89.96 \\
& Pemukiman & $0-8$ & 408.53 & & TK & \\
\cline { 2 - 8 } Pakuniran & H. Industri & $0-8$ & 391.9 & 391.9 & AK & 10.04 \\
\cline { 2 - 8 } & Sawah & $0-8$ & 946.53 & 1450.14 & TK & 14.46 \\
& Pemukiman & $0-8$ & 156.01 & & TK & \\
& H. Primer & $8-15$ & 347.6 & & TK & \\
\cline { 2 - 8 } & Sawah & $8-15$ & 485.83 & 682.57 & PK & 6.81 \\
& Pemukiman & $8-15$ & 196.74 & & PK & \\
\cline { 2 - 8 } & H. Primer & $25-40$ & 5887.5 & 6567.58 & AK & 65.50 \\
& Lhn.Terbuka & $8-15$ & 130.67 & & AK & \\
& H. Industri & $8-15$ & 549.41 & & AK & \\
\cline { 2 - 8 } & H. Industri & $25-40$ & 196.23 & 196.23 & K & 1.96 \\
\cline { 2 - 7 } & Tegal & $25-40$ & 436.01 & 1131.01 & SK & 11.28 \\
& Lhn.Terbuka & $25-40$ & 695.00 & & SK & \\
\hline
\end{tabular}

TK = Tdk Kritis, PK = Potensi Kritis, AK = Agak Kritis, $K=$ Ktiris, $\mathrm{SK}=$ Sangat Kritis

Status kerusakan tanah sedang yang meliputi wilayah kecamatan Sumber Asih, Bantaran, Tegal Siwalan, Krejengan dan Pakunira diakibatkan parameter berat isi (b). komposisi koloid dan fraksi pasir (f). derajat pelulusan air (p) dan redoks (r). Keterangan lebih rinci disajikan dalam tabel 20.

\section{Penetapan dan Pemetaan Status Kekritisan Lahan}

Penetapan status keritisan lahan diperlukan beberapa parameter yang mempengaruhi kekritisan lahan, meliputi: kemiringan lahan, tutupan lahan, kehilangan tanah.

\section{Kemiringan Lahan}

Hasil analisa kemiringan lahan berdasarkan Peraturan Dirjen Pengendalian DAS dan Hutan Lindung Nomor P.3/PDASHL/SET/KUM.1/7/2018, di 7 kecamatan wilayah penelitian bervariasi, mulai dari datar sampai curam. Kemiringan lahan masing-masing kecamatan disajikan dalam tabel 21, dan gambar 2. 


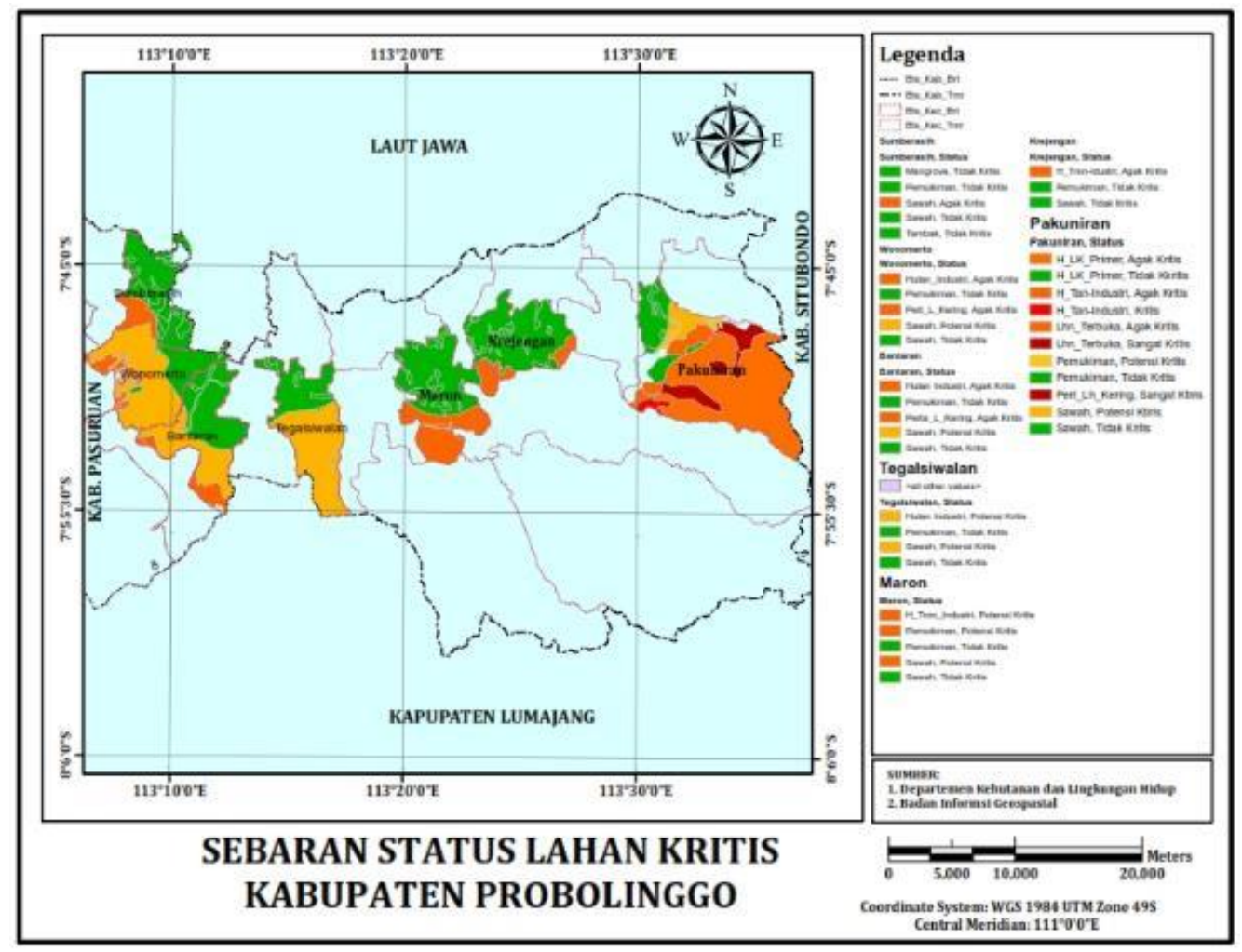

Gambar 5. Sebaran status kekritisan lahan di wilayah penelitian.

\section{Tutupan Lahan}

Penutupan lahan merupakan tutupan biofisik permukaan bumi yang merupakan hasil pengaturan, aktivitas, dan perlakuan manusia yang dilakukan pada jenis penutup lahan tertentu untuk melakukan kegiatan produksi, perubahan, ataupun perawatan pada areal tersebut. Analisis tutupan lahan didasarkan pada Peraturan Dirjen Pengendalian DAS dan Hutan Lindung Nomor P.3/PDASHL/SET/KUM.1/7/2018. Hasil analisa tutupan lahan di 7 kecamatan wilayah penelitian di kelompokkan menjadi Hutan, Sawah, pemukiman, tambak, lahan kosong, dan tegal. Persentase dan luasan masing-masing tutupan di 7 kecamatan disajikan dalam tabel 22, dan gambar 3.

Dari tabel 22 tutupan lahan untuk masing-masing kecamatan daerah penelitian menunjukkan persentase dan luasan yang tidak sama. Kecamatan Pakuniran didominasi oleh hutan sebesar $69,62 \%$ atau seluas 6980,74 ha, dan terrendah tutupan pemukiman sebesar 3,52\% atau seluas 352,75 ha. Tutupan lahan dikecamatan Krejengan didominasi oleh sawah sebesar $79,5 \%$ atau seluas 3103,17 ha, dan terrendah tutupan hutan sebesar 10,04\% atau seluas 392,9 ha. Kecamatan Maron didominasi $82,73 \%$ atau seluas 4253,78 ha oleh sawah, dan hutan hanya menduduki 6,43\% atau seluas 330,69 ha. Untuk kecamatan Tegalsiwalan, Bantaran, Wonomerto dan Sumberasih masing-masing didominasi oleh tutupan sawah berturut-turut sebesar 94,48\% (4244,35 ha), 83,85\% (3694,21 ha), $85,06 \%$ ( 4083,99 ha) dan $78,17 \%$ atau ( 2420,47 ha).

\section{Kehilangan Tanah (Erosi)}

Besarnya kehilangan tanah diduga dengan menggunakan persamaan umum kehilangan tanah yang telah dikembangkan oleh Wischmeier dan Smith (1978) dan Anasiru (2015), yaitu E = R x K x L x S x C x P. Parameter hitung kehilangan tanah seperti yang dijelaskan di atas didapatkan besarnya erosi tanah di daerah penelitian disajikan dalam tabel 23, dan gambar 4 .

Daerah yang tidak kritis sebagian besar merupakan daerah yang terdapat di dataran rendah sampai sedang. yaitu lahan sawah dan tegal. Lahan kategori ini menduduki sekitar 43,35\% dengan kecamatan Pakuniran memiliki sebaran paling luas sekitar 33,09\% dan yang paling kecil kecamatan Tegalsiwalan sebesar 5,58\%. Lahan kategori ini juga perlu mendapatkan perhatian yang serius terutama untuk tegal. Lahan tegal sering kali pada musim kemarau tidak ada vegetasi penutupnya, dan sebagian besar pemilik lahan enggan mengelolanya. Hal ini akan mendorong terjadinya lahan potensial kritis baru. Sedangkan lahan dengan kategori agak kritis menempati proporsi luas sebesar 19,82\% dari total luas wilayah. Pemanfaatan lahan yang termasuk kategori agak kritis perlu diperhatikan dengan serius agar tidak memacu degradasi kualitas lahan. Lahan dengan kategori kritis dan sangat kritis menempati proporsi luas kurang lebih 2,32\% dari total luas daerah.

Dari tabel 23 terlihat bahwa besarnya erosi untuk masing-masing kecamatan daerah penelitian menunjukkan persentase dan luasan yang tidak sama. Kecamatan Pakuniran erosi terbesar terjadi pada lahan terbuka sebesar 52,07\% dari total erosi yang ada di kecamatan tersebut, dan terrendah pada penggunaan lahan sawah sebesar $2,55 \%$. Kejadian erosi di 
kecamatan Krejengan terbesar pada penggunaan lahan untuk pemukiman sebesar $61,36 \%$ dan terrendah pada penggunaan hutan sebesar $1,25 \%$. Kecamatan Maron mengalami erosi tanah sebesar $58,06 \%$ pada lahan pemukiman sedangkan erosi tanah terrendah sebesar $13,25 \%$ pada lahan sawah. Besarnya kehilangan tanah di kecamatan Tegalsiwalan terbesar pada penggunaan lahan sawah sebesar $61,81 \%$ dan terendah pada lahan hutan yaitu 2,29\%. Untuk kecamatan Bantaran, dan Wonomerto kehilang tanah terbesar pada lahan sawah yaitu sebesar $39,86 \%$ dan $62.69 \%$. Sedangkan kecamatan Sumberasih erosi terbesar dialami pada penggunaan pemukiman yakni $79,89 \%$.

\section{Pemetaan Status Kekritisan Tanah}

Memanfaatkan Sistem Informasi Geografi (SIG) memudahkan dalam analisis kebutuhan dan tindakan rehabilitasi hutan dan lahan daerah aliran sungai (DAS) yang efektif dan efisien. sehingga dapat mengeliminir kekurangan yang terjadi akibat kegiatan manual. Keunggulan lain penggunaan data digital yaitu dalam proses sintesis dan analisis lebih lanjut dapat dilakukan dengan cepat dan tepat. Kondisi tersebut sangat bermanfaat untuk meningkatkan kinerja dari para pengambil kebijakan (policy maker) yang terkait dengan pengelolaan hutan dan lahan (Renyut. Kumurur dan Karongkong, 2018).

Data yang diperlukan dalam penelitian ini adalah peta topografi. peta kontur. peta tanah. peta wilayah administrasi. citra satelit Landsat. peta penggunaan lahan. dengan skala peta 1 : 50.000. Untuk analisa dan sintesis data kuantitatif dilakukan dengan: a) pengkelasan. scoring dan pembobotan dengan skala dan kriteria seperti telah ditetapkan dalam SK Dirjen RRL No. 041/Kpts/V/1998. dan b). yang dilanjutkan dengan melakukan tumpang susun bertahap setiap layer peta (peta kelas lereng. peta penutupan lahan. peta sebaran tanah. peta manajemen). sehingga dihasilkan klasifikasi lahan kritis (Nugroho dan Prayogo, 2008).

Penetapan status kekritisan lahan diperoleh dengan menggunakan ArcMap GIS versi 10.6 dengan menggabungkan dan menumpangsusunkan layer-layer penutupan lahan, kemiringan lahan, bahaya erosi dan kawasan atau wilayah administrasi.

Penyebaran lahan kritis di 7 kecamatan kabupaten probolinggo pada dataran medium sangat dipengaruhi oleh geologi dan geomorfologi yang ada di wilayah tersebut. Kondisi lahan di 7 kecamatan tersebut dipengaruhi oleh aktivitas vulkan dan iklimnya yang basah sehingga tanahnya bersifat sangat subur. sehingga pemanfaatan lahannya didominasi oleh budidaya pertanian (baik lahan basah maupun pertanian lahan kering).

Ditinjau dari fisiografi. daerah penelitian terbagi menjadi dua wilayah. yaitu: (1) Wilayah dataran menengah yang terletak di bagian utara gunung Bromo dan sebelah barat laut gunung Argopuro. Mengingat kondisi tanahnya subur. wilayah ini banyak dimanfaatkan untuk pertanian. (2) Wilayah dataran rendah yang membentang sampai laut Jawa. Berdasarkan analisis spasial dengan teknik tumpangsusun (overlay) dan skoring terhadap parameter penentuan lahan kritis menurut Peraturan Dirjen Pengendalian DAS dan Hutan
Lindung Nomor P.3/PDASHL/SET/KUM.1/7/2018, diperoleh data spasial lahan kritis untuk 7 kecamatan di kabupaten Probolinggo. Hasil analisis menunjukkan bahwa di daerah penelitian mempunyai luas lahan 36.017,68 ha, dengan klasifikasi sebagai berikut : tidak kritis seluas $15.613,22$ ha $(43,35 \%)$. Potensial kritis $10.942,66$ ha $(30,38 \%)$, agak kritis seluas $8.134,56$ ha $(22.58 \%)$. kritis seluas 196,23 ha $(0,54 \%)$ dan sangat kritis seluas $1.131,01$ ha $(3,14 \%)$, dengan sebaran lahan tidak kritis. Potensial kritis, agak kritis, kritis dan sangat kritis dimasing-masing kecamatan seperti dalam Tabel 24. Sedangkan sebaran lahan kritis di masing-masing kecamatan disajikan dalam Gambar 5.

\section{KESIMPULAN}

Berdasarkan hasil identifikasi status kerusakan dan kekritisan lahan dapat disimpulkan bahwa status kerusakan tanah adalah termasuk rusak ringan kecamatan Wonomerto dan Maron dan rusak sedang kecamatan Tegalsiwalan, Bantaran, Krejengan, Pakuniran, Sumber Asih. Status kekritisan lahan diwilayah 7 kecamatan yang memiliki luas $36.017,68$ ha, dengan status tidak kritis seluas $15.613,22$ ha $(43,35 \%)$. Potensial kritis $10.942,66$ ha $(30,38 \%)$, agak kritis seluas $8.134,56$ ha $(22.58 \%)$. kritis seluas 196,23 ha $(0,54 \%)$ dan sangat kritis seluas1.131,01 ha $(3,14 \%)$.

\section{DAFTAR PUSTAKA}

Anasiru, R. H., Jl, B. P. T. P. G., \& Tilongkabila, B. B. (2015). Perhitungan laju erosi metode USLE untuk pengukuran nilai ekonomi ekologi di Sub DAS Langge, Gorontalo. Jurnal Pengkajian dan Pengembangan Teknologi Pertanian, 18(3),273-289.

Aronoff, S. (1989). Geographic information systems: a management perspective, WDL Publication, Otawa, Canada.

Ashari, A. (2013). Kajian tingkat erodibilitas beberapa jenis tanah di pegunungan baturagung desa putat dan nglanggeran kecamatan patuk kabupaten gunungkidul. Informasi, 39(2).

Banuwa, I. I. S. (2013). Erosi. Prenada Media.

Didu, M. S. (2011). Analisis posisi dan peran lembaga serta kebijakan dalam proses pembentukan lahan kritis. Jurnal Teknologi Lingkungan, 2(1).

Nugroho, S. P. (2008). Penerapan SIG untuk penyusunan dan analisis lahan kritis pada satuan wilayah pengelolaan DAS Agam Kuantan, Provinsi Sumatera Barat. Jurnal Teknologi Lingkungan, 9(2).

Peraturan Pemerintah RI. P No. 150 Tahun 2000. Pengendalian Kerusakan Tanah Untuk Produksi Biomassa. 
Permenhut Nomor P.32/Menhut-II/2009. Tata Cara Penyusunan Rencana Teknik Rehabilitasi Hutan dan Lahan Daerah Aliran Sungai (RTkRHL-DAS)

Peraturan Dirjen Pengendalian DAS dan Hutan Lindung Nomor P.3/Pdashl/Set/Kum.1/7/2018 Tentang Petunjuk Teknis Penyusunan Data Spasial Lahan Kritis.

Peraturan Pemerintah Nomor 26 Tahun 2020. Tentang Rehabilitasi dan Reklamasi Hutan. LN.2020/NO.137, TLN NO.6518, JDIH.SETNEG.GO.ID : 28 HLM. https://peraturan.bpk.go.id/Home/Details/138323/ppno-26-tahun-2020

Raharjo, B., \& Ikhsan, M. (2015). Belajar ArcGIS Desktop 10. Geosiana Press. Hal 306-340

Ramayanti, L. A., Yuwono, B. D., \& Awaluddin, M. (2015). Pemetaan tingkat lahan kritis dengan menggunakan penginderaan jauh dan sistem informasi geografi (studi kasus: Kabupaten Blora). Jurnal Geodesi Undip, 4(2), 200-207.

Renyut, L. R., Kumurur, V., \& Karongkong, H. H. (2018).
Identifikasi Dan Pemetaan Lahan Kritis Dengan Menggunakan Teknologi Sistem Infomasi Geografis (Studi Kasus Kota Bitung). SPASIAL, 5(1), 92-104.

Sunggono B., (2020). Badan Pusat Statistik Kabupaten Probolinggo. CV. Azka Putra Pratama. Halaman 1117

Wahyuni, E. D., Mukaromah, S., \& LU, W. (2017). Web GIS Tutupan Lahan Dengan Menggunakan Google Map dan Google Earth. Jurnal Sistem Informasi Dan Bisnis Cerdas (SIBC), 10.

Wahyuningrum, N., \& Basuki, T. M. (2019). Analisis kekritisan lahan untuk perencanaan rehabilitasi lahan das solo bagian hulu. Jurnal Penelitian Pengelolaan Daerah Aliran Sungai (Journal of Watershed Management Research), 3(1), 27-44.

Wischmeier, W. H., \& Smith, D. D. (1978). Predicting rainfall erosion losses: a guide to conservation planning (No. 537). Department of Agriculture, Science and Education Administration. 